\title{
Recent trends for the removal of colored particles in industrial wastewaters
}

\author{
Abu Zahrim Yaser $^{1}$ (D) Ravindra Pogaku ${ }^{1}$
}

Received: 6 June 2017 / Accepted: 14 June 2017 / Published online: 30 June 2017

(C) Springer-Verlag GmbH Germany 2017

The global textile and apparel industry is among major sector in the world, with China, India European Union, and United States being the major textile exporters. According to 2015 statistics, the current value of world textiles-apparel exports totaled US\$736 billion (World Trade Organization 2016). On the other hand, oil palm, commercially named as Elaeis quineensis Jacq., is one of the main agricultural crops in tropical countries, especially Malaysia and Indonesia being leaders. The main traded commodities are crude palm oil (CPO), crude palm kernel oil (CPKO), and palm kernel cake (PKC).

The major CPO producing countries are Indonesia, Malaysia, and Thailand; other countries such as Colombia, Nigeria, Guatemala, Ecuador, Honduras, Papua New Guinea, Ghana, etc. are also contributing for crude palm oil. The United States Department of Agriculture (USDA) reported that the global palm oil production in 2016 was 58.8 million metric tons (United States Department of Agriculture 2016).

The similarity between textile and apparel and crude palm oil industries is colored effluents. The color of

Responsible editor: Philippe Garrigues

Abu Zahrim Yaser

zahrim@ums.edu.my

1 Chemical Engineering Programme, Faculty of Engineering, Universiti Malaysia Sabah, Jln UMS, 88400 Kota Kinabalu, Sabah, Malaysia textile industry effluent is due to synthetic dye while the latter is due to lignin, tannin, and other plant based colorants. Both industries produce colored effluents in large quantities. The presence of residual colored particles in surface water is esthetically undesirable and causes annoyance to the aquatic biosphere due to reduction of sunlight penetration and depletion of the dissolved oxygen. Due to their toxic and recalcitrance properties, colored particles can also contribute to the failure of biological processes in wastewater treatment plants. Further, the regulations imposed for the discharged colored effluents have become more stringent and thus motivated the industries to improve their effluent de-colorization technology. In this regard, it is the right time for the release of this special issue to highlight some of the advanced techniques for effluents decolorization. Generally, there are two de-colorization methods: by destruction of colored particles (e.g., chemical oxidation and bio-oxidation) and the other is by separation of colored particles from water (e.g., coagulation-flocculation, sand filtration and membrane separation).

This special issue on Recent Trends for the Removal of Colored Particles in Industrial Wastewaters includes, a selection of papers presented at the 6th International Conference on Pollution and Treatment Technology (PTT 2016) held from July 25 to 27, 2016 in Suzhou, China. All the selected papers were subjected to rigorous peer-review process as followed for regular submission process to Environmental Science and Pollution Research journal. Ultimately, five papers were accepted for publication in the Environmental Science and Pollution Research Special Issue entitled "Recent 
Trends for the Removal of Colored Particles in Industrial Wastewaters".

It is interesting to note that this special issue covered chemical, physical, and biological aspect of decolorization technology. Coagulation-flocculation is one of the most widely applied methods in de-colorization due to its low cost and easy operation, but the selection of suitable coagulants is critical to ensure higher coagulation performance. Tamrim and Zahrim employed multiple-objective optimization on the basis of ratio analysis (MOORA) to discretely measure multiple response characteristics of five different types of coagulants as a function of assessment value. Reuses of palm oil mill effluent were reported to be a suitable substrate not only to produce biohydrogen but also to increase the economics of photo fermentation via waste utilization. Budiman et al. suggested that moderate ultrasonication pre-treatment was an effective technique to improve bio-hydrogen production performances of Rhodobacter sphaeroides. The large surface area, modified surface properties, unique electron conduction properties, etc. offer nanomaterials with excellent performances in dye-contaminated effluent de-colorization. Jie $\mathrm{Fu}$ et al. comprehensively reviewed the innovative methods to treat dye-contaminated effluents using nanomaterials.

Another recent technique, membrane separations have been recognized as a key tool for wastewater recycle/ reuse. Despite its extraordinary price, ceramic membrane can still be able to surpass polymeric membrane, in the applications that require high temperature and pressure conditions, as well as harsh chemical environment. Othman et al. reported preparation of kaolin hollow fiber membrane via dry/wet phase, inversion-based spinning technique and sintering process for the removal of reactive black 5 (RB5) dye solution. Finally, Rahman et al. discusses the preparation and characterizations of glass hollow fiber ultrafiltration membranes prepared using zeolite-5A as a starting material.

\section{References}

World Trade Organization (2016) World Trade Statistical Review. Website: https://www.wto.org/english/res_e/statis_e/wts2016_e/ wts2016_e.pdf. Access on 6 June 2017.

United States Department of Agriculture (2016) http://www. globalpalmoilproduction.com/. Access on 6 June 2017.

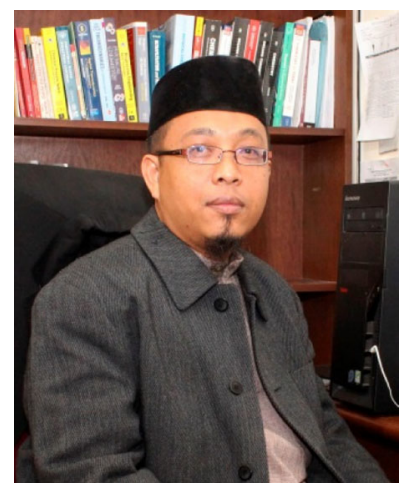

Abu Zahrim Yaser is Head of Waste Management Committee and senior lecturer at Chemical Engineering Programme, Universiti Malaysia Sabah (UMS). He has obtained his $\mathrm{PhD}$ from Swansea University (UK). To date, Dr. Zahrim has published six book chapters, 22 journals, and $50++$ other publications. His paper, "Treatment of highly concentrated dye solution by coagulation/ flocculation-sand filtration and nanofiltration", published in Water Resources and Industry (2013) has been one of the most highly cited papers during 2014-2016. He is awarded as an outstanding reviewer for several Elsevier journals. He was the secretary for the 4th International Conference on Chemical and Bioprocess Engineering (ICCBPE 2012) and the Workshop on Progress in Wastewater Treatment and Reuse Technology (PWTRT-2013). He is the recipient of Universiti Malaysia Sabah Excellent Service Award (2015). Dr. Zahrim is a visiting scientist at the University of Hull and a member of Institutions of Chemical Engineers (United Kingdom), Board of Engineers (Malaysia), and Malaysia Water Association.

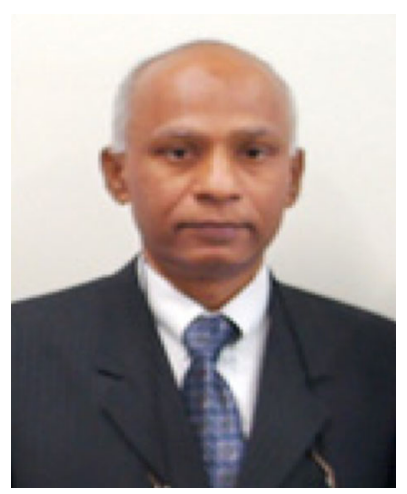

Dr. Ravindra Pogaku has diverse and intense, yet rewarding experiences in teaching, research, industry, executive, and administrative fields spanning over 35 years. He was a visiting professor at the Pennsylvania State University and Cornell University, USA. Professor Pogaku has an expertise in the area of bioprocess engineering for high value products, biofuels, and bioenergy. Over the course of his 35 years, he has published more than 225 articles in journals and proceedings, edited four books, authored eight books, and 12 book chapters. He has reviewed more than 1200 journal manuscripts for reputed international journals. He has two patents and four copyrights. Professor Pogaku is bestowed with the national and international prestigious awards. Professor Pogaku was recipient of distinguished chemical engineer award from the Indian Institute of Chemical Engineers. He has received the best researcher award from the International Journal of Science and Technology. He was also a UNESCO consultant on sustainable energy projects. Professor Pogaku has been receiving the award of excellence from the University of Malaysia for the last 4 years, consecutively. Prof. Pogaku is an external examiner and panel member for many universities. He has also carried out at least 25 major industrial project studies. He serves as the editor-in-chief, editorial board member, guest editor, and reviewer for multiple referred journals. Professor Pogaku has delivered invited lectures, plenary talks and keynote address at various national and international institutions, symposia, conferences, etc. He is also an advisory committee member for international conferences. Professor Pogaku has organized short-term refresher courses, workshops, conferences, and seminars. His focus is on the green engineering and technology for sustainable development of the society. 